\title{
Ordem Temporal e Inferência Causal
}

\author{
Warren E. Miller
}

Arizona State University

\begin{abstract}
Resumo
Medidas de mudança em pares de variáveis atitudinais podem proporcionar insights Importantes sobre a estrutura dos sistemas de crenças políticas dos públicos de massa. Dados de painéis revelam evidências da grande centralidade de alguns elementos de idéias em vez de outros no contexto de constrangimento dinâmico de curto prazo. A especificação dos atributos teoricamente relevantes dos eleitores torna possível testar diferenças estruturais esperadas que conectam predisposições relacionadas a políticas e preferências por políticas; a especificação também torna possível testar proposições que envolvem os efeitos recíprocos de atitudes e preferências emergentes de voto. Algumas das especificações mais úteis revelam até que ponto a heterogeneidade da população produz uma imagem embaçada de relações quando a análise se baseia no eleitorado total, em vez de se limitar a eleitores ou subconjuntos de eleitores especificados por critérios teóricos.
\end{abstract}

Palavras-chave: sistemas de crenças, variáveis atitudinais, preferências eleitorais, relação causal

\begin{abstract}
Measures of change in pairs of attitudinal variables can provide important insights into the structure of the political belief systems of mass publics. Panel data reveal evidence of the greater centrality of some idea elements rather than others in the context of short-term dynamic constraint. Specification of the theoretically relevant voter attributes makes it possible to test for expected structural differences connecting policy related pre-dispositions and policy preferences; specification also makes it possible to test propositions involving the reciprocal effects of attitudes and emerging vote preferences. Some of the more helpful specifications disclose the extent to which population heterogeneity produces a blurred image of relationships when analysis is based on the total electorate rather than limited to voters or subsets of voters specified by theoretical criteria.
\end{abstract}

Key words: belief systems, attitudinal variables, vote preferences, causal relation 


\section{Introdução}

O tratamento da causalidade na versão de 1960 de The American Voter (Campbell et al. 1976) foi, no mínimo, desigual. De um lado, uma preocupação constrangida com o tópico levou a um capítulo no livro e à metáfora do Funil da Causalidade. ${ }^{1}$ Ao mesmo tempo, a tese de que cada elemento fenomenológico discernível tinha provavelmente múltiplas causas - e assim, cada causa teria seu próprio conjunto de múltiplas causas - levou os autores a desistir de montar uma estrutura explicativa que desse conta da seqüência infinita de causas e efeitos que produzem uma única decisão de voto.

Na obra seguinte, The New American Voter, a causalidade é de novo um tema central. A análise progride com a elaboração de várias interpretações possíveis e alternativas dos "efeitos" das diferentes variáveis sobre a decisão do voto. The New American Voter tenta organizar as muitas causas das decisões dos eleitores com um modelo explícito de causas e conseqüências. O modelo é fornecido por uma estrutura de explicações bloco-recursivas ${ }^{2}$, de múltiplos estágios, em que há uma primeira tentativa de se prevenir contra a aceitação de evidências espúrias de ligações causais.

Este ensaio foi desenvolvido a partir dos esforços de criar "provas secundárias" relevantes para pressupostos sobre a ordem temporal das variáveis - causa e efeito empregadas em The New American Voter. O livro baseia-se quase inteiramente em dados de survey longitudinal. Este ensaio baseia-se em dados de pesquisa painel que conectam sucessivos períodos de tempo.

A fase inicial da pesquisa aqui relatada enfocou o papel da identificação partidária como influência - ou causa -, com várias predisposições relacionadas com políticas e preferências em questões políticas como efeitos. Um algoritmo muito simples para tabular distribuições bivariadas de dados de painel produziu regularidades empíricas fascinantes que são uma mistura não óbvia de artefato metodológico e significação substancial. Para demonstrar o significado substancial dos resultados, explorou-se uma série de perspectivas analíticas/teóricas. Os resultados pareceram autenticar a interpretação substantiva que se buscava e também têm implicações para outras questões mais amplas sobre a estrutura das atitudes e opiniões políticas dos eleitores em eleições presidenciais. Embora o ensaio comece e conclua com uma ênfase na seqüência temporal e na ordem causal das classes de conceitos inter-relacionadas - refletida nas operações de pesquisa usando dados longitudinais - chama-se a atenção para outros temas analíticos.

\footnotetext{
${ }^{1}$ A criação da metáfora precedeu o término do manuscrito do livro. Ela fazia tanta parte da nossa maneira de pensar e falar sobre o estudo da decisão do eleitor que um funil de aço de hospital foi o brinde dos membros do seminário de 1958 sobre comportamento eleitoral patrocinado pelo SSRC. No funil estava escrito: "Um funil não tem células vazias". O melhor da ocasião foi inadvertidamente captado pela gravação no funil dos doze símbolos do código de uma coluna com as 12 linhas/80 colunas do cartão perfurado da IBM.

${ }^{2}$ Recurso de análise de adição de variáveis e repetição em múltiplos estágios.
} 


\section{A determinação da causalidade}

\section{A causalidade e a análise do comportamento eleitoral}

$\mathrm{Na}$ literatura sobre comportamento eleitoral, uma versão comum do problema geral de estabelecer uma seqüência causal pergunta se a identificação partidária "causa" a preferência por determinadas políticas e as avaliações de desempenho, ou se estas últimas "causam" a identificação partidária. De modo mais geral, parece que a identificação partidária encontra-se em algum lugar entre ser um elemento exógeno que influencia muitos valores, percepções, crenças e atitudes, sem ser influenciada por nenhum deles, e, do outro lado, ser apenas outra atitude política de curto prazo.

Para a abordagem de Miller/Shanks do estudo do comportamento eleitoral, o problema é mais ubíquo do que um interesse singular pelo status teórico causal da identificação partidária. Seja na forma do modelo bloco-recursivo um tanto incômodo de dez estágios utilizado em nossa análise da eleição de 1988 (Shanks e Miller 1991), ou com a estrutura simplificada de seis estágios adaptada para a análise de 1992 (Miller e Shanks 1996), tentamos alinhar e combinar uma grande quantidade de variáveis discretas que representam muitos conceitos importantes diferentes em um conjunto de equações bloco-recursivas simples. Em alguns casos, a teoria substantiva sugere uma seqüência causal para ordenar os blocos de conceitos - pode-se supor que predisposições políticas relevantes (valores ou crenças valorizadas) podem, a curto prazo, levar a referências sobre questões políticas do momento. ${ }^{3}$ Em outros casos, a ordem temporal da evolução das variáveis aparentemente resolve todas essas questões (a instrução dos eleitores dificilmente pode ser causada pelas expectativas sobre as futuras condições econômicas). Contudo, outras situações permanecem ambíguas: a identificação partidária é determinada por preferências políticas anteriores, ou os militantes seguem uma linha partidária em questões de diretrizes políticas? Este ensaio descreve um procedimento analítico para extrair dados empíricos que podem constituir "provas secundárias" úteis para resolver questões deste tipo.

\section{A lógica da ordem causal}

O ponto de partida dessa discussão, com raízes numa extensa literatura sobre análise causal, está numa monografia pouco citada de James A. Davis (1985). Embora Davis, em última análise, aborde e renove aspectos da obra clássica de Alwin e Hauser (1975) sobre análises de efeitos, bem como de Kendal e Lazarsfeld (1950) e Rosenberg (1968) sobre elaboração multivariada e Sewell Wright (1921) sobre análise de trajetória, o

\footnotetext{
${ }^{3}$ Ver Zaller (1992:22-23) para uma variante da definição de predisposição. Em geral, estamos de acordo com Zaller, mas não classificamos características sociais e econômicas, que são freqüentemente os antecedentes de predisposições atitudinais, como predisposições. Em vez disso, identificamos várias predisposições relacionadas com políticas, tais como atitudes com respeito a igualitarismo, com antecedentes relevantes tais como raça e religião.
} 
ponto a ser destacado é a ênfase de Davis no fato de que todas essas abordagens tratam explicitamente a causalidade como um processo que ocorre ao longo do tempo. De uma forma ou de outra, qualquer explicação causal de alguma ocorrência dependente deve incluir o fato de que a causa de um efeito precedeu o efeito.

Os cientistas sociais tendem a pensar a causalidade em termos de "mudanças em $X$ produzem mudanças em $Y$ '. Com freqüência, a questão supostamente respondida pela análise de regressão é: quantas unidades de mudança em $Y$ estão associadas a, ou são produzidas por cada unidade de mudança em $X$ ? A própria formulação da questão supõe que a relação de ordem no tempo entre $X$ e $Y$ já foi estabelecida. Este ensaio preocupa-se com a necessidade anterior de estabelecer a seqüência ordenada no tempo. Começamos por observar que colocar a questão como ela é convencionalmente formulada obscurece a possibilidade de que mudanças em $Y$ possam, em algum sentido, ser "causadas" por $X$ sem qualquer mudança em $X$. Davis (1985), em sua atualização das discussões clássicas de Lazarsfeld e Rosenberg, faz a afirmação crucial de que pode ocorrer que uma mudança observável somente em $Y$ seja o elemento inicial definidor que indica a ocorrência de um processo causal. Ele sustenta que dois padrões de mudança numa relação bivariada constituem dois casos especiais do "grande princípio da ordem causal: depois não pode causar antes ... não há maneira de mudar o passado ... as flechas unidirecionais (indicando a direção da causalidade) correm com o tempo". Davis especifica então os dois casos complementares: "Variável $X$ é uma causa da Variável $Y$ quando - mudança em $X$ (mais cedo ou mais tarde) produz mudança em $Y$-, ou (porque alguns Xs não mudam), Ys tendem a se alinhar com valores fixos de $X$ ". A persuasão exercida por líderes políticos resulta no "alinhamento" dos adeptos com seus respectivos líderes. Esse padrão de mudança pode ser representado por uma questão como a ação afirmativa, quando eleitores fiéis a partidos mudam suas preferências para acompanhar as posições previamente estabelecidas pelos líderes do partido. O ponto básico de que a covariância, significando um processo causal, pode mudar se ou a variável "independente" ou a "dependente" muda é também defendido poderosamente por Ruy Teixeira (1984).

Qualquer dos dois processos de mudança produzirá a evidência familiar de covariância ligando causa e efeito. Porém, a covariância pode também ser resultado de um terceiro processo em que um terceiro fator, talvez em existência antes de $X$ e $Y$, provoca mudanças na relação entre $X$ e $Y$. O truque de diagnóstico quando se trabalha com dados longitudinais é, naturalmente, estabelecer qual dos três processos está por trás de qualquer relação observada no ponto singular no tempo. Neste ensaio, estamos buscando maneiras de explorar dados de painel para entender melhor as relações entre variáveis que podem ser observadas em dados longitudinais estáticos. 


\section{Experimentos, dados longitudinais e painéis}

À medida que avançamos, é útil não esquecer a diferença entre a interpretação causal dos resultados de um experimento e a interpretação análoga de uma relação bivariada produzida a partir de um survey longitudinal. No primeiro, a covariância entre $X \mathrm{e}$ $Y$ é gerada pela produção de diferentes valores em uma variável dependente, $Y$, variandose deliberadamente a experiência do sujeito com alguma variável independente, $X$. Dois conjuntos de mensurações em cada variável, "antes" e "depois" podem ser feitos, ou inferidos, demonstrando que a mudança particular foi feita por um agente determinado. Porém, no caso das distribuições bivariadas extraídas de dados longitudinais, observa-se covariância (expressa convencionalmente como uma correlação ou um coeficiente de regressão) somente entre valores presumivelmente dependentes e independentes, expostos após o fato, por uma variedade de "sujeitos". Há um único ponto no tempo (ou uma série de pontos no tempo para sucessivos cortes longitudinais) para medir ambas as variáveis simultaneamente, sem nenhuma evidência direta de que um conjunto de variações em uma variável precede e, portanto, produziu ou causou o segundo.

Os dados de painel, diferentemente, podem ser considerados quase experimentais, apesar da falta de controle sobre a introdução de variáveis experimentais, na medida em que cada variável "dependente" e "independente" pode ser medida para mudança individual entre dois pontos no tempo, "antes" e "depois". A relação entre elas pode ser medida em ambos os momentos, mas, mais do que isso, pode-se observar se a mudança em uma variável é congruente com a não-mudança de valor de outra.

Com dados de um painel de duas ondas é possível identificar dois dos três processos que resultam numa relação causal entre variáveis independentes e dependentes: (1) é possível observar ambas as variáveis mudarem de uma maneira congruente ou compatível (presumivelmente, o efeito de uma causa comum); ou (2) como observa Davis, a mudança observável em uma variável resulta em ela "alinhar-se com" ou "ficar mais congruente com" a outra. Dados de painel de três ondas são necessários para observar o terceiro caso mais convencional em que uma mudança em $X$ produz subseqüentemente mudanças compatíveis ou congruentes em $Y$. Em vez de um experimento controlado, o painel de três ondas é necessário porque $T_{1}$ e $T_{2}$ são necessários para medir e observar as mudanças em $Y$, enquanto que $T_{2}$ e $T_{3}$ são necessários para observar mudanças conseqüentes em $Y$, que podem então ser interpretadas como variações em $Y$ causadas por mudanças em $X$.

Sem recorrer pelo menos a dados de painel não-experimentais não é possível observar a seqüência temporal que está no âmago da análise causal. $O$ melhor que alguém pode fazer com dados de um único corte no tempo é estabelecer configurações que sejam consistentes com a suposição de uma seqüência causal, sem provas de que as mudanças realmente ocorreram na ordem temporal postulada. Provas secundárias da maior estabilidade de uma variável em relação à outra conduzem à suposição de que a mais estável é a causa mais provável se, de fato, as duas estão ligadas causalmente. E 
quando uma "teoria forte" sustenta um argumento, isso pode dar credibilidade à suposição de uma seqüência causal unidirecional. Análises longitudinais sucessivas também podem revelar uma sucessão de configurações cambiantes ao longo do tempo que sejam consistentes com a noção de que uma variável se torna de fato mais congruente com outra (Miller e Shanks 1982). Mas somente com dados longitudinais, a suposição de uma seqüência causal não pode ser submetida a um teste independente crucial para tranqüilizar os céticos. É por isso que correlações post hoc entre duas variáveis não são, por elas mesmas, consideradas provas suficientes de causalidade ou de uma relação causal.

Em meio à sua discussão das regras que governam a lógica da ordem causal, Davis (1985) observa que "as regras não têm nada a ver com a estatística. Embora as publicações de metodologia fervilhem com propostas malucas para determinar a ordem causal usando somente os números de um conjunto de dados, a maioria dos metodólogos concorda que a ordem causal é um problema substantivo ou empírico para ser resolvido com nosso conhecimento sobre como o mundo real funciona, não por rodopios estatísticos". Compartilho a preocupação de Davis em enfatizar a lógica temporal dos processos causais, mas creio também que algumas estatísticas muito simples baseadas na seqüência temporal podem proporcionar a base para esclarecer o modo como o mundo real funciona. A seqüência temporal de mudanças cambiantes entre variáveis pode ser captada e tornada explícita em dados de painel com a tabulação de valores seqüencialmente cambiantes das variáveis inter-relacionadas. Para produzir essas tabulações, devemos evitar resumir distribuições bivariadas como coeficientes de correlação e reter a apresentação detalhada da distribuição subjacente a esses coeficientes.

\section{Uma representação tabular da ordem causal}

Para fazer isso, devemos ir além do uso que Davis fez de dados longitudinais para representar (como fizeram Kendall, Lazarsfeld e Rosenberg em seus trabalhos pioneiros) a lógica da elaboração com tabulações multivariadas de dados de survey. Com dados de painel em que ambas as variáveis foram medidas em não menos de dois pontos no tempo, podemos examinar as distribuições bivariadas de padrões de estabilidade e mudança em cada uma das duas variáveis. Podemos identificar casos de um padrão genérico em que uma variável não muda entre $T_{1}$ e $T_{2}$, enquanto que uma segunda variável muda, e muda para melhor concordar, conformar-se ou "alinhar-se" com o valor imutável da primeira. Talvez a segunda variável esteja, na verdade, se ajustando a uma terceira variável $Z$, que tem uma relação estabelecida com $X$. Todavia, quando existe o padrão de um aumento na congruência de duas variáveis, o tomamos como evidência 
consistente com, ou que sustenta plausivelmente, uma interpretação que a primeira variável pode ter de alguma forma causado uma mudança na segunda. ${ }^{4}$ Porém, como todas as atribuições de "significado" a uma configuração de dados, a "prova" de uma interação ou relação causal está na combinação entre teoria substantiva e uma interpretação metodológica das manipulações de dados.

Antes de examinar o caso clássico de "mudança em $X$ produz mudança em $Y$ ", continuemos com o caso menos familiar do painel de duas rodadas e façamos uma ilustração concreta de nossos procedimentos de tabulação. ${ }^{5}$ Chamemos a identificação partidária de $A$ e de $B$ a auto-classificação ideológica, talvez um substituto para preferências gerais em questões políticas. A escolha dessas duas variáveis não é acidental. O estudante profissional das pesquisas de comportamento eleitoral as reconhecerá como as duas atitudes ou predisposições básicas importantes para a interpretação de muitas eleições. Porém, não temos certeza sobre a relação causal entre elas. Após a eleição de 1984, Shanks e Miller deram precedência à ideologia como causa parcial da identificação partidária porque, entre 1980 e 1984, a distribuição marginal da ideologia era aparentemente a mais estável das duas. Em 1988, a ordem foi invertida (Shanks e Miller 1990, 1991) e, em 1992, concluímos que realmente não sabíamos o suficiente para classificar uma como causa e a outra como efeito. É mais do que incidental nossa curiosidade sobre a possibilidade de descobrir um meio de esclarecer a interrelação entre elas.

Nas ilustrações que seguem, por motivos didáticos e para minimizar a intrusão de erros de mensuração, diferenciamos somente três categorias de cada variável. Para identificação partidária, temos democratas, independentes e republicanos; as designações ideológicas compreendem liberais, moderados e conservadores. Começamos por definir os possíveis padrões de estabilidade e mudança na identificação partidária com a tabela de mudança de voto de nove células gerada entre $T_{1}$ e $T_{2}$. Isso é apresentado genericamente na Figura 1, onde $D=+, I=0$ e $R=-$. Em seguida, definimos os possíveis padrões de mudança em uma localização ideológica por uma tabela similar e substantivamente congruente em que $L=+, M=0$ e $C=-$. Estabelecidas essas

\footnotetext{
${ }^{4}$ Não é preciso dizer que tudo só faz sentido se há um continuum direcional subjacente sobre o qual ambas as variáveis podem compartilhar significado, e se há uma direção clara para um efeito potencial de $X$ em $Y$ (ou vice-versa). Se, em geral, tanto antes como depois da mudança em $X$, não é provável que os republicanos favoreçam $Y+$ mais do que os democratas e não é provável que os democratas favoreçam $Y$ - mais do que os republicanos, é improvável que as mudanças de $Y+$ para $Y$ ofereçam uma interpretação causal do partidarismo em nossa esquema limitado de coisas. Os padrões de mudança entre dois pontos no tempo devem ser interpretáveis como proporcionando uma melhor adequação, mais congruência ou mais acordo entre duas variáveis que são reflexos de qualidades ou atributos bem diferentes se queremos que os padrões sejam interpretados como indícios de uma relação causal, e não simplesmente como exemplo de uma tautologia ou de confiabilidade na mensuração operacional de um único conceito. Esse o ponto em que as operações de pesquisa e a teoria substantiva definem as variáveis a ser examinadas e propõem razões para esperar uma outra flecha dominante-causal.

${ }^{5}$ Embora as referências ortodoxas sustentem que $X$ é a causa e $Y$ a conseqüência, em nossa tentativa de obter novas provas relativas à direção causal, os padrões de mudança devem ser operacionalmente definidos de forma que a direção imputada de uma flecha causal seja igualmente livre para ir de $Y$ para $X$ ou de $X$ para $Y$. Para evitar os papéis tradicionais de " $X$ " e" $Y$ ", usamos $A$ e $B$ em toda a nossa discussão, sem supostos a priori relativos à direção dominante da causalidade.
} 
convenções, as distribuições de estabilidade e mudança para as duas medidas, identificação partidária e preferência ideológica, podem ser representadas como na Figura 1.

\section{FIGURA 1}

Transformação de uma tabela de mudança de voto $T_{1}-T_{2}$ em uma distribuição em nove categorias de uma única variável em dois pontos no tempo.

$\mathrm{T}_{1}$

\begin{tabular}{|c|l|l|l|}
\multicolumn{1}{c|}{$\mathrm{T}_{2}$} \\
\cline { 2 - 4 } \multicolumn{1}{c|}{+} & \multicolumn{1}{c|}{0} & \multicolumn{1}{c|}{-} \\
\hline+ & $4(+,+)$ & $7(+, 0)$ & $9(+,-)$ \\
\hline 0 & $2(0,+)$ & $5(0,0)$ & $8(0,-)$ \\
\hline- & $1(-,+)$ & $3(-, 0)$ & $6(-,-)$ \\
\hline
\end{tabular}

Em seguida, admitimos a comparabilidade essencial dos elementos dentro das tríades que designam 1, 2 e 3 como instâncias de mudança numa direção pró-democrata, 4, 5 e 6 como três instâncias de ausência de mudança no partidarismo e 7, 8 e 9 como três instâncias de mudança na direção pró-republicana. Do mesmo modo, aceitamos (1) três padrões de preferência ideológica que retratam mudança numa direção pró-liberal, (2) outros três que não retratam mudança na posição ideológica e (3) três padrões de mudança na direção pró-conservadora. Podemos então gerar as 81 células de uma distribuição bivariada de mudanças nas duas variáveis. Elas estão implícitas na Figura 2. Tendo em vista a comparabilidade pressuposta dos elementos que representam mudança, ou ausência de mudança, em cada variável (partidarismo e ideologia), as 81 células podem ser organizadas e simplificadas, em resumo, sob dez classificações. ${ }^{6}$

\footnotetext{
${ }^{6}$ Ao igualar os três casos em cada conjunto de mudanças para cada variável, descartam-se evidentemente informações pertinentes à magnitude das mudanças. Porém, isso parece ser consistente com o recente argumento de Rubinowitz e MacDonald (1989) que favorece a ênfase direcional, em vez de posicional, em modelos de escolha de eleitores baseadas na prioridade relativa percebida das classificações dos candidatos.
} 
FIGURA 2

Esquema analítico ilustrativo para identificar os padrões mais plausíveis de influência causal que envolvem causalidade recíproca por duas variáveis.

Variável B (auto-classificação ideológica) $\mathrm{T}_{1}-\mathrm{T}_{2}$

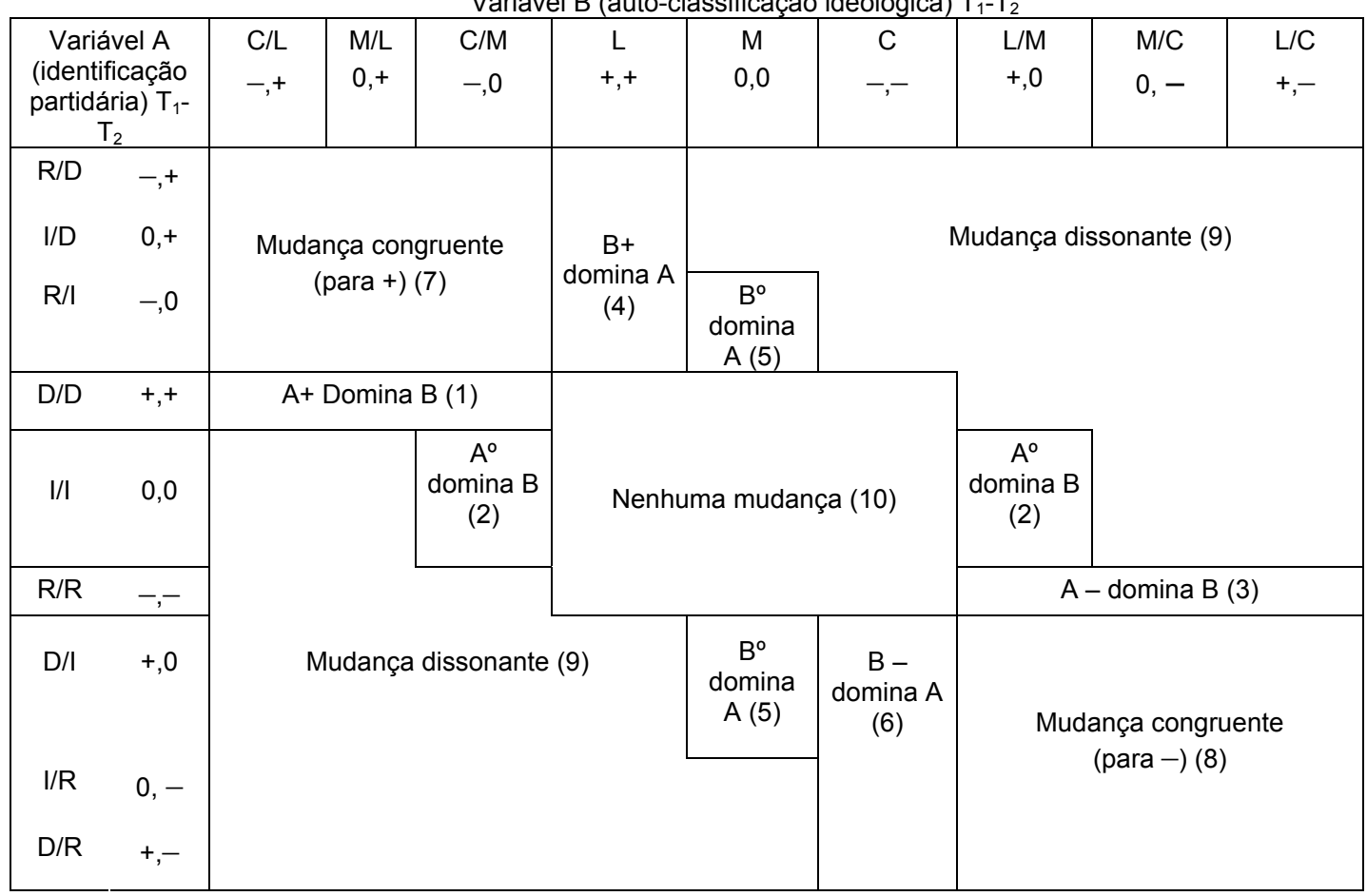

Por exemplo: os casos designados por (1) na Figura 2 exibem mudanças em preferências ideológicas que resultam numa maior conformidade com preferências (estáveis) democratas. $A$ é + (democrata) tanto em $T_{1}$ como em $T_{2} . B$ muda de - para + ( $C$ para $L)$, de - para $0(C$ para $M)$, ou de 0 para $+(M$ para $L)$. Esses três exemplos de mudança ideológica que criam maior concordância com a identificação partidária encorajam a conclusão de que o partido (estável) é a causa e a posição ideológica mudada é o efeito.

Os casos (2) e (3) também mostram preferências ideológicas mudando para conformar-se à identificação partidária, mas agora para os que se identificam com independentes e republicanos, respectivamente.

As instâncias complementares em que o partido muda para adequar-se melhor à ideologia estável, imutável, são marcados com (4), (5) e (6), correspondendo a um movimento no sentido de preferências ideológicas liberais, moderadas e conservadoras, respectivamente.

Nos casos (7) e (8), não é plausível nenhuma interpretação causal da relação entre partido e ideologia, pois ambos mudam na mesma direção "liberal" ou "conservadora" entre $T_{1}$ e $T_{2}$, talvez em reação à mudança em algum terceiro fator ou 
conjunto de fatores. Por fim, os casos designados por (9) mostram um aumento de divergência ou discrepância entre preferência partidária e posição ideológica e os (10) não sofreram nenhuma mudança. Ambas as categorias impossibilitam a inter-relação causal de curto prazo.

Nosso esquema de categorização envolve algumas simplificações grosseiras e a tricotomia inicial ignora informações relativas a magnitudes da mudança, mas nada disso parece violentar a lógica básica que governa uma interpretação da direção da causalidade na relação entre $A$ e $B .^{7}$ Tanto quanto saibamos, a novidade dessa classificação tabular de dois padrões variáveis de estabilidade e mudanças impede qualquer referência a uma literatura que corrobore sua validade.

A destruição de casos entre as primeiras seis categorias pode simplesmente indicar a proporção de casos que se enquadram em uma ou outra das duas estruturas simples que envolvem causalidade unidirecional. As categorias 1, 2 e 3 na Figura 2 sugerem que a variável imutável $A$ (identificação partidária) está associada com, ou "causou" mudanças na variável $B$ (auto-classificação ideológica). A amplitude em que as categorias 4-6 ocorrem é a mesma em que a ordem $A$ antes de $B$ é invertida. A relativa preponderância de 1-3 e 4-6 é, portanto, uma medida da amplitude em que uma ou outra seqüência causal é "dominante" na população no período de tempo examinado. Não há nada na definição operacional dos padrões causais que dê a $A$ ou $B$ uma vantagem a priori como agente causal dominante. Ambos os padrões são notáveis por seu explícito contraste com a suposição normal de que uma variável causa mudança em outra somente quando uma mudança documentada na primeira é seguida por uma devida mudança observável na segunda.

\section{Mudando contextos: o papel dos estímulos exógenos}

A suposição de que a mais estável das duas variáveis unidas numa relação causal pode realmente ser a "causa de mudança" independente na variável dependente leva a uma elaboração adicional sobre os modos comuns de pensar sobre a causalidade. A lógica da experimentação, que está por trás de boa parte de nosso pensamento, em geral reconhece explicitamente apenas duas variáveis na produção de um efeito: uma variável dependente, que muda quando a variável independente é manipulada (introduzida no experimento ou alterada em seu valor). Mas se a suposta variável

\footnotetext{
${ }^{7}$ A decomposição de padrões de estabilidade e mudança atitudinal em dez categorias também convida para uma exploração interessante das interpretações causais dadas às mudanças em $T_{1}$ e $T_{2}$ na correlação entre duas variáveis. A exploração pode ser introduzida comprimindo as dez categorias em 4: (1) mudanças interpretáveis como conseqüência de interação causal (16), em que a correlação entre variáveis aumenta fortemente; (2) mudanças em que ambas as variáveis se movem na mesma direção (7 e 8), sem mudança substancial em correlações; (3) mudanças que levam à divergência (9) que produz um forte declínio ou inversão das correlações entre $T_{1}$ e $T_{2}$; e (4) ausência de mudança na correlação (10). Para o intervalo de tempo em análise, somente as mudanças na primeira categoria (1-6) sustentam uma interpretação causal de mudanças em $T_{1}$ - $T_{2}$ em correlações totais de $A$ e $B$, mas cada uma das quatro categorias tem um impacto sobre as relações totais entre as duas variáveis nos dois pontos do tempo.
} 
independente não muda e a variável dependente muda - entrando em maior conformidade ou se alinhando com a variável independente, a existência de um terceiro contribuidor para a relação causal torna-se aparente como uma condição necessariamente lógica para a produção de um "efeito". Algo deve ter acontecido (análogo ao experimentador criando a mudança em $X$ ) para mudar a variável dependente, talvez com a ativação de $X$ ou uma acentuação da relevância da variável causal imutável $X$ para a conseqüente variável dependente mudada $Y$. Há um sentido claro em que um terceiro elemento deve ser a causa próxima anterior precipitadora. No experimento, ele aparece na forma do processo do experimento. No presente contexto, pode assumir a forma de um aspecto de uma campanha, ou uma mudança na circunstância eleitoral, ou talvez a simples passagem do tempo que pode ocorrer enquanto os cidadãos conciliam conflitos internos ou inconsistências em suas atitudes e percepções. (Esse "terceiro elemento" não deve ser confundido com o "terceiro fator", que pode ser um antecedente comum responsável pela correlação entre $X$ e $Y$.)

Infelizmente para nosso modelo analítico - ou para a maioria dos modelos de comportamento eleitoral -, não temos geralmente medida sistemática de qualquer dos elementos (além da passagem do tempo) nesse terceiro conjunto. Nos últimos quarenta anos, o conteúdo dos estudos eleitorais expandiu nossa cobertura de todos os tipos de variáveis "independentes" e "dependentes", mas raramente saímos da psique do cidadão para medir os instrumentos de mudança concretos, a intervenção dos eventos e circunstâncias do mundo externo ao eleitor. Felizmente, a crescente consciência do problema levou muitos estudiosos a adornar as coletas de dados de surveys com a adição de dados contextuais (Bartels 1988). Contudo, até mesmo o mais elaborado "dado contextual" costuma ser insuficiente para medir sistematicamente a magnitude, a intensidade, a duração ou a relevância das intervenções contextuais.

$O$ fracasso em avaliar as causas externas ou exógenas mediante medidas explícitas impõe uma possível restrição severa a nossas avaliações da importância causal de diferentes blocos de variáveis. No mínimo, fica aberta a possibilidade de que diferenças que parecem distinguir uma eleição de outra em relações que envolvem a escolha de voto podem não se dever obviamente a mudanças ou diferenças nos fatores iniciais, intrapsíquicos empregados em nossas análises, variáveis que designamos (e analiticamente ordenamos) como mais ou menos independentes e dependentes. Por exemplo, as preferências dos eleitores por determinadas políticas podem ter sido essencialmente constantes entre eleições, mas produzem diferenças entre eleições devido a diferenças na relevância das preferências por políticas para as diferentes escolhas de voto. As diferenças podem dever-se à ativação das assim chamadas preferências "independentes", não a mudanças nas preferências. Outro exemplo: a relevância da identificação partidária de alguém para sua preferência ideológica pode depender do grau em que as campanhas dos candidatos promovam ou enfatizem a conexão entre partido e ideologia. Se assim for, independente de qual das duas variáveis 
mude, é o comportamento do candidato que causa a mudança de um cenário para outro. Nesse caso, devemos achar algum modo de introduzir variações de comportamento do candidato na análise sistemática se quisermos compreender as ligações entre identificação e ideologia.

Uma vez que as mudanças de que estamos tratando resultam todas em aumento de congruência ou conformidade com um tema comum subjacente, é também bastante possível, como sugerimos, que o terceiro elemento seja simplesmente o tempo. O aumento de "acordo", "congruência" ou "conformidade" implica alguma resolução de conflito ou redução de tensão que pode envolver não mais do que o processo mental de redução da dissonância psicológica. Um desacordo sentido entre o senso de localização ideológica de alguém e uma preferência política pode ser resolvido com a mudança de uma ou outra. O processo dessa resolução de conflito pode ser iniciado por um evento externo próximo, mas não necessariamente. Todavia, o reconhecimento de tais padrões básicos de relações envolvidas no deslinde das causas do comportamento eleitoral deve certamente levar a mudanças no desenho de futuros estudos e na atenção aos problemas de mensuração em futuras coletas de dados.

\section{Estudos de caso}

\section{Identificação partidária e ideologia em 1990-1991 e 1991-1992}

No restante dessa discussão é posto de lado o problema colocado pela falta de informação sobre o elemento crucial que induz ou produz mudanças mensuráveis em um painel de duas ondas. Simplesmente aceitamos o fato da mudança em uma das variáveis sem inquirir sobre a causa externa próxima. Concentramo-nos na seqüência temporal de mudanças nas duas variáveis. Primeiro, examinamos diretamente os dados de painéis tratados de forma a deixá-los o mais comparáveis possíveis, empregando medidas operacionalmente idênticas de duas variáveis, no primeiro exemplo, identificação partidária (IP) e auto-classificação ideológica. A primeira apresentação é obtida do recente painel do National Election Studies (NES) americano que faz a ponte entre o ano nãoeleitoral de 1990, o ano da Guerra do Golfo (1991) e o ano eleitoral de 1992. Na Tabela 1, a segunda coluna usa 1990 e 1991 como $T_{1}$ e $T_{2}$ respectivamente; na terceira coluna $T_{1}$ é 1991 e $T_{2}$ é 1992.

De acordo com nosso esquema de classificar as muitas células em nossa tabela de mudança de voto para duas variáveis em dois pontos do tempo (Figura 2), a categoria modal em ambos os intervalos de tempo era "Nenhuma mudança" em ambas as variáveis. Porém, o impacto de refluxo do ano não-eleitoral de 1990 e a conseqüência energizadora de uma eleição presidencial que se aproxima podem ter-se refletido no pequeno decréscimo no tamanho do grupo "Nenhuma mudança" no segundo intervalo de tempo 
(de $53 \%$ para $49 \%$ ). O mesmo efeito disciplinador da aproximação de uma eleição nacional talvez se reflita também na incidência menor de mudança dissonante no mesmo intervalo de tempo (de $25 \%$ par $22 \%$ ). Esses dois fatos produziram mais congruência de partido e ideologia com a aproximação da eleição presidencial.

Há também uma sugestão de um papel visível muito limitado de "terceiros fatores" que pode ser responsável pela mudança congruente em ambas as variáveis, ou que pode ser responsável por influências muito mais importantes que não podem ser deslindadas dentro dos intervalos de tempo captados pelo painel. O número de casos de aparente mudança conjunta na mesma direção não chega a 4\% do painel entre 1990 e 1991 e chega apenas a 6\% entre 1991 e 1992.

\section{TABELA 1}

Padrões plausíveis de influência causal entre identificação partidária e auto-classificação ideológica ${ }^{a}$

\begin{tabular}{|c|c|c|c|c|}
\hline & $1990-1991$ & & 1991-1992 & \\
\hline & $(\%)$ & & $(\%)$ & \\
\hline \multicolumn{5}{|l|}{ Causas plausíveis } \\
\hline 1. IP democrata & 4,3 & & 7,7 & \\
\hline 2. IP independente & 4,3 & & 2,7 & \\
\hline 3. IP republicano & 3,7 & & 3,7 & \\
\hline Subtotal & & 12,3 & & 14,1 \\
\hline 4. Ideologia liberal & 0,7 & & 3,4 & \\
\hline 5. Ideologia moderada & 2,6 & & 2,0 & \\
\hline 6. Ideologia conservadora & 3,0 & & 4,3 & \\
\hline Subtotal & & 6,3 & & 9,7 \\
\hline \multicolumn{5}{|l|}{ Outros Padrões } \\
\hline $\begin{array}{l}\text { 7. Nenhuma interação causal; ambos } \\
\text { foram para a esquerda }\end{array}$ & 1,0 & & 3,2 & \\
\hline $\begin{array}{l}\text { 8. Nenhuma interação causal; ambos } \\
\text { foram para a direita }\end{array}$ & 2,6 & & 2,8 & \\
\hline 9. Nenhuma interação causal; divergência & 24,8 & & 21,5 & \\
\hline $\begin{array}{l}\text { 10. Nenhuma interação causal; nenhuma } \\
\text { mudança }\end{array}$ & 53,3 & & 48,8 & \\
\hline Subtotal & & 81,7 & & 76,3 \\
\hline Total & & 100,0 & & 100,0 \\
\hline$(\mathrm{N})$ & & $(705)$ & & $(562)$ \\
\hline
\end{tabular}

a Dados do Painel NES, 1990-1991-1992, postos à disposição pelo Inter-University Consortium for Political and Social Research. Os números que designam as dez categorias correspondem aos atribuíduos na Figura 2. Nota: a soma das colunas não dá exatamente $100 \%$ devido a erros de arredeondamento. 
Em conseqüência dos três padrões (nenhuma mudança, mudança dissonante e mudança congruente simultânea) que frustram a interpretação de uma interação causal entre partido e ideologia, o resto dos números disponíveis para a interpretação causal de uma tal relação entre as duas variáveis é cerca de $18 \%$ do total, no primeiro intervalo, e $24 \%$, no segundo. Ainda que tenhamos certas expectativas bastante específicas sobre qual padrão de direção causal predominará quando somente duas variáveis estão envolvidas (IP para ideologia, ou ideologia para IP), há pouca base a priori para esperar ou supor outra coisa. Em particular, temos pouca base para qualquer predição sobre a incidência relativa dos vários padrões que acabamos de identificar.

Não sabemos se a mudança que se ajusta a padrões plausíveis de causalidade envolvendo essas duas predisposições geralmente estáveis deveria valer para $5 \%, 10 \%$, $20 \%$ ou mais de um painel de um ano, depois ou logo antes de uma eleição. As porcentagens de $18 \%$ e $24 \%$ para intervalos de um ano são altas, baixas ou médias? Sabemos pouco sobre o ritmo provável de mudança que pode ocorrer ou sobre as condições que acelerariam ou amorteceriam a mudança no papel de ambas as variáveis. Como vai diferir o ritmo de mudança para diferentes variáveis? Que conseqüências tem a aproximação de uma eleição presidencial para as relações entre variáveis formadas um, dois ou quatro anos antes? Que intervalo de tempo deve transcorrer sob quais condições para que ocorra uma mudança apreciável? Intervalos de alguns meses, um ano, dois anos ou quatro anos proporcionam cenários comparáveis para que ocorra mudança e ela seja estudada? ${ }^{8}$ Estamos apenas começando a entender as mudanças políticas de longo prazo na política americana e temos uma compreensão comparativamente menor das mudanças de curto prazo.

Não obstante, se nosso raciocínio até aqui está correto, talvez possamos usar nossa nova visão da covariância bivariada ao longo do tempo para descobrir o que pode ter ocorrido. O estabelecimento da possível predominância de um padrão causal sobre outro é apenas um produto - e concebivelmente o menos importante - da linha de indagação que se abre com nossa descrição tabular de estabilidade e mudança entre pares de variáveis.

\section{Identificação partidária e auto-classificação ideológica: causa ou efeito?}

Examinando os indícios relevantes para nossa curiosidade inicial sobre a relação entre partido e ideologia, que padrão de suposta influência causal predominou entre 1990 e 1991? No primeiro intervalo de tempo, os dados da Tabela 1 dão suporte ao argumento de que a trajetória causal vai com mais freqüência do partidarismo para a ideologia do que

\footnotetext{
${ }^{8}$ A falta de precisão de nossa disciplina para compreender as condições que promovem mudança ou afetam taxas de mudança infesta a interpretação de dados de opinião pública durante uma campanha. Quantas mudanças na posição das corridas de cavalos deveriam ser produzidas por quais eventos? E, por inferência, quanto são os outliers conseqüências prováveis do método de coleta de dados? Ver Campbell e Garand (2000).
} 
da ideologia ao partido, por uma substancial razão de 12,3 para 6,3 (66 a 34). Houve quase o dobro de casos em que a identificação partidária não mudou entre 1990 e 1991, enquanto que as mudanças em ideologia produziram uma maior conformidade com o partido assim como houve casos opostos (em que a ideologia estável foi seguida por identificação partidária). No segundo intervalo anterior à eleição de 1992, a direção predominante da influência causal foi do partidarismo como causa para a ideologia como conseqüência, mas por uma margem um pouco menor de 14.1 para 9,7 (59 a 41). Ao longo do período de dois anos, de 1990 a 1992, a seqüência dominante de mudanças teve a identificação partidária como causa primária e a ideologia como efeito.

Mas há evidentemente muito mais coisas para dizer. Em primeiro lugar, as margens de 2 para 1 ou 3 para 2 significam que houve grandes minorias para as quais a ordem dominante em cada seqüência analítica estava "errada". Em ambos os intervalos, parece que uma quantidade substancial de indivíduos mudou seu sentimento de fidelidade partidária para ajustar-se a suas posições ideológicas imutáveis. Isso é uma prova clara de que, qualquer que seja a ordem analítica que escolhamos, ela não será apropriada para algumas pessoas, pelo menos durante algum tempo. Isso sublinha o reconhecimento crucial de que qualquer ordenação ótima será, como em praticamente todos os modelos, somente a melhor "média" adequada para uma população heterogênea.

Porém, de qualquer modo, a direção substantiva das mudanças líquidas parece combinar com a história do período. De 1990 a 1991, o movimento geral foi da esquerda para a direita ( $6 \%$ indo para a direita, enquanto $5 \%$ foram na direção oposta), em larga medida porque os conservadores ideológicos continuaram a se mudar para o Partido Republicano (Shanks e Miller 1991). Mas entre 1991 e 1992, a direção do movimento mudou. Possivelmente como prelúdio de um surto democrata nas urnas, o movimento em direção à esquerda democrata superou os movimentos em direção à direita republicana por uma margem de 11 a $8(11,1$ a 8,0$)$.

A direção da mudança entre pessoas para as quais ambas as variáveis mudaram em direções congruentes segue o mesmo padrão: para a direita republicana entre $1990 \mathrm{e}$ 1991 e para a esquerda democrata - por uma pequena margem - entre 1991 e 1992. Tudo somado, cerca de um quarto da população do painel $(22,2 \%$ no primeiro intervalo, $29,8 \%$ no segundo), por uma margem de 3 para 2 (60 a 40), mudou sistematicamente de identificação partidária ou localização no continuum ideológico (ou ambas) no intervalo de dois anos.

Para ampliar nossa investigação sobre relações causais entre pares de variáveis, há uma variedade de pesquisas painéis de duas rodadas que podem ser exploradas com a confiança de que todas as variáveis foram criadas por exatamente as mesmas operações de medida. A mais elaborada, dois painéis de seis meses, vem do painel intraano do NES, janeiro-junho-outubro de 1980. O painel do CPS de 1972-1974-1976 oferece duas comparações familiares de dois anos. Tendo em vista o projeto do NES para estudos de anos não eleitorais, há muitos painéis disponíveis da década recente. Porém, 
alguns dos dados mais interessantes vêm do estudo mais antigo de Jennings sobre socialização política e mudança de atitude (Jennings e Niemi 1981). O painel de longo prazo do estudo mais antigo de Jennings é mais interessante teoricamente porque os contrastes entre resultados empíricos de análises tanto de um painel de pais quanto de um painel de filhos são muito grandes.

Dada a natureza nova de nosso paradigma tabular, atacamos agora em duas frentes: procuramos indícios de causalidade predominante na relação entre membros de vários pares de variáveis e, ao mesmo tempo, exploramos circunstâncias que podem testar a validade de nossas interpretações. Por exemplo, o painel de longo prazo de uma parte do estudo de Jennings oferece várias configurações que parecem muito interessantes em ambas as frentes.

\section{Diferenças de geração: o painel de Jennings}

O intervalo de tempo de particular interesse para nós no painel de Jennings abrange um período de mudanças rápidas na política nacional americana. O primeiro ponto no tempo para nossa análise é 1973, quando uma amostra nacional de alunos de último ano do segundo grau de 1965 foi entrevistada novamente, assim como seus pais. O segundo ponto no tempo que usamos desses dois painéis é 1982, quase uma década depois. ${ }^{9}$ Entre os filhos - cujas idades mudaram de 25-26 para 34-35 entre 1973 e 1982 houve uma quase paridade entre os dois padrões direcionais de suposta influência envolvendo identificação partidária e ideologia liberal/conservadora entre $1973\left(T_{1}\right)$ e 1982 $\left(T_{2}\right)$. Ao longo de nove anos, cerca de $10 \%$ da coorte mais jovem demonstrou partidarismo estável, com um aumento na conformidade ideológica ao partido; de modo inverso, a ideologia "prevaleceu" e produziu mudanças conformes na opção partidária entre $9 \%$ da coorte. Nesse grupo jovem e relativamente bem instruído, cujos membros não poderiam ter participado mais do que das duas eleições presidenciais de 1968 e 1972 antes de $T_{1}$ (1973), a identificação partidária foi pouco mais estável - ou causalmente dominante - do que o fenômeno menos comum da auto-classificação ideológica.

Em contraste, o painel de pais observou- se não tivesse efetivamente votado pelo menos sete eleições presidenciais, com freqüência, desde o período anterior à Segunda Guerra Mundial e o New Deal. A idade dos pais variava entre os quarenta e muitos e os cinqüenta e poucos anos em $1973\left(T_{1}\right)$, e de mais de cinqüenta a mais de sessenta em $1982\left(T_{2}\right)$. Para esse conjunto relativamente maduro de adultos, a direção causal vai do partido (como causa) à ideologia (como efeito) em três de cada quatro casos (16\% a $5 \%)$. O período de turbulência política durante os primeiro quinze anos de vida adulta da geração dos filhos produziu respostas deles que eram bem diferentes das respostas dos pais, que tinham vivido os sucessos políticos relativos do New Deal, da

\footnotetext{
${ }^{9}$ Infelizmente, o primeiro intervalo do estudo não pode ser usado para nossos propósitos devido à ausência de medidas comparáveis de identificação partidária e ideologia em 1965 e 1973. Ver Jennings e Niemi (1981).
} 
Segunda Guerra e da prosperidade do pós-guerra. O padrão dos pais exibia a dominância da identificação partidária, formada em larga medida sob o governo de Franklin $D$. Roosevelt e o New Deal. O contraste com a quase paridade de partido com a ideologia liberal-conservadora entre seus filhos é uma prova direta de que a afiliação partidária pode de fato estabilizar e fortalecer com a idade e, portanto, aumentar sua centralidade no processo que molda outras atitudes e percepções políticas.

Nossa técnica para traçar seqüências temporais de mudança em busca de supostas provas da direção da causalidade pode ter a importante conseqüência de proporcionar testes como o que acabamos de observar para algumas das propriedades teóricas das variáveis sob investigação. Tais testes podem revelar teoricamente variações relevantes na estabilidade e centralidade de qualquer variável dada envolvida em processos causais da formação de atitudes, valores e crenças. Na medida em que os resultados de testes intencionais não forem embaçados por erros de mensuração e mudanças idiossincráticas, parece que seremos também lembrados insistentemente de que a heterogeneidade de qualquer população "natural" pode desafiar a descoberta de qualquer processo causal uniforme e único que seja compartilhado por todos os membros. Ao mesmo tempo em que aprendemos sobre o grau em que uma ordenação de variáveis é manifestamente inapropriada para alguns membros da população em estudo, podemos saber mais sobre ambas as variáveis e as pessoas em exame.

De direta relevância para a análise eleitoral, as coortes de pais e filhos no estudo de Jennings também refletem padrões contrastantes nas relações entre identificação partidária e preferências por políticas específicas. Em 1973 e também e 1982, perguntouse aos membros de ambos os painéis sobre suas preferências em duas questões políticas muito diferentes. A primeira pergunta era se aprovavam ou desaprovavam que o governo tivesse um papel ativo nos assuntos domésticos, garantindo a disponibilidade de empregos e a manutenção de um "bom padrão de vida". Entre os pais, a interpretação causal presuntiva das conexões entre essas preferências e a identificação partidária favoreceu o partido como causa por uma proporção de mais de 2 para $1(16 \%$ a $7 \%)$. Na coorte dos filhos, o partido foi dominante, mas a razão foi somente de 12 para 10.

Diferenças mais pronunciadas apareceram sobre a questão de se os Estados Unidos deviam ter intervindo no Vietnã. Na geração dos pais, o partido novamente dominou como causa, embora pela proporção menor de 16 para 10. Porém, entre os filhos, a direção causal dominante inverteu-se, das atitudes sobre o Vietnã como "causa" para a mudança de identificação partidária como "efeito" por uma sólida proporção de 13 para 8. Isso é um indício mais do que sugestivo de que enquanto as lealdades partidárias ainda estão se cristalizando em jovens adultos, as preferências políticas que estão no centro do debate contemporâneo podem desempenhar um importante papel na moldagem dessas lealdades. É interessante observar que embora o sentimento anti-Vietnã fosse a causa presumida mais freqüente em ambas as gerações (em vez dos sentimentos próintervenção), a proporção anti-Vietnã/pró-Vietnã para os filhos foi somente de 9 para 4 , 
em comparação com 9 para 1 entre seus pais. A esta altura, não podemos dizer se os sentimentos da geração mais velha estavam simplesmente refletindo velhos "valores democratas liberais" que persistiam enquanto novas lealdades partidárias se criavam entre seus filhos.

Contudo, outras diferenças geracionais que foram posteriormente bem documentadas por muitas outras fontes estavam claras nos dados de 1982 de Jennings. Em sua opção partidária, a principal coorte da geração pós-New Deal - os baby boomers do final dos anos 80 e começo dos 90 - veio a ser tão desequilibrada - 72 democratas para 28 republicanos - quanto seus pais da geração New Deal (71 democratas para 29 republicanos). Porém, eles eram muito mais "conservadores" do que os mais velhos. Quanto à preferência ideológica, os filhos se dividiram em 49 conservadores e 51 liberais, enquanto os mais velhos se dividiram em 23 conservadores e 77 liberais. Essa diferença entre gerações corre em paralelo com as diferenças de atitudes em relação à intervenção dos EUA no Vietnã. (Tudo isso, é claro, entre os $75 \%$ de famílias cujos filhos não deixaram a escola antes do último ano do segundo grau e numa época em que as mudanças da era Reagan na opção partidária da população não haviam diminuído a vantagem que os democratas levavam desde o New Deal.)

Deve-se observar que esses arautos do futuro eram visíveis somente em um em cinco de cada geração que exibia os padrões de mudança aos quais estamos atribuindo significado causal. Tanto no estudo de Jennings como em vários outros estudos nos quais tocamos brevemente no resto deste artigo, parece que outros $40 \%$ a $50 \%$ de qualquer população dada de cidadãos em idade de votar não mostram mudanças em qualquer membro de qualquer par de variáveis durante intervalos de um ano ou mais, antes ou depois de uma eleição. $O$ restante, freqüentemente uma parcela apreciável, divide-se então entre um punhado em que ambos os membros de um par variável mudam em uníssono (talvez refletindo um terceiro fator comum) e um conjunto muito maior em que as atitudes refletidas no par de variáveis divergem umas da outras e, portanto, desafiam qualquer interpretação causal fácil. Em resumo, padrões de mudança sistemáticos ou interpretáveis parecem geralmente confinados aos casos identificados por variáveis com valores convergentes.

\section{Uma advertência sobre erro de mensuração}

Antes de avançar mais no estudo das relações causais entre os membros de pares variáveis, devemos observar de novo quão pouco sabemos sobre as propriedades estatísticas dos procedimentos analíticos que estamos usando. Em particular, sabemos muito pouco sobre a possível confusão que resulta de erro de mensuração ou de mudança aleatória. Uma vez que supomos geralmente que os erros de mensuração diminuem o aparecimento de confiabilidade de medida (ver Green e Palmquist [1990] para uma aplicação à mensuração de identificação partidária), pode seguir-se que - como 
sugerimos antes - um esquema analítico que iguala dominância em relações causais com a maior estabilidade medida de uma variável individual seja vulnerável a acusações de validade limitada devido à intrusão de erro de mensuração. Quanto mais erro, maior a probabilidade da incidência de mudança "conformante"; quanto menos erro, maior a probabilidade do aparecimento de estabilidade dominante. Essa possibilidade não pode ser ignorada, mas há várias abordagens de uma avaliação sistemática da seriedade do problema.

No decorrer da exploração de possíveis interpretações substantivas, aproveitamos a oportunidade para observar a estabilidade ou confiabilidade convencionalmente medida de uma dada variável em relação à confiabilidade medida de outras variáveis com as quais foi unida na busca de relações causais plausíveis. Por exemplo, nas análises do painel do NES de 1990-1991-1992, examinamos cerca de 50 pares de variáveis. Em 18 casos, a mais alta confiabilidade teste-reteste, $T_{1}-T_{2}$, de uma variável (comparada com a outra) estava de fato associada com um papel causal aparentemente dominante da variável mais estável. Ou para dizer de outro modo, nesses 18 casos, uma autocorrelação intra-item $T_{1}-T_{2}$ mais baixa para uma variável estava associada à interpretação de a variável ser com mais freqüência "causada" pela outra variável mais estável. Porém, em 32 casos, a proporção da causa presumida para o efeito foi contradita pela proporção baixa confiabilidade/alta confiabilidade. Em outras palavras, em 32 de 50 casos não se podia atribuir a maior incidência de direção causal simplesmente a uma maior confiabilidade de mensuração da variável aparentemente dominante porque, na verdade, essa variável não era medida com mais estabilidade ou confiabilidade.

Uma vez que 18 dos 50 pares (18 diferentes dos acima) envolviam identificação partidária, a qual é, por larga margem, a mais confiável de todas as variáveis políticas, é interessante examiná-los separadamente. Em 11 dos 18 casos envolvendo identificação partidária, essa identificação aparece de fato como a mais confiavelmente medida, bem como é a "causa" dominante; nos outros sete pares, o partido também foi medido como a variável mais confiável, mas não devia ser interpretado como a variável causal dominante. Dados os números para todos os 50 pares, nos outros 32 casos restantes que não envolviam identificação partidária, somente sete casos baseavam-se em que a maior confiabilidade univariada estava associada com dominância causal; em 25 casos, a variável que dominava como causa putativa exibia menos confiabilidade (uma correlação $T_{1}-T_{2}$ menor) do que o "efeito" presumido.

Outros testes menos diretos parecem diminuir ainda mais a probabilidade de que as interpretações de direção causal dominante sejam, na verdade, a simples conseqüência de mudança aleatória ou erro de mensuração. Não obstante, há circunstâncias em que uma provável intrusão do problema de mensuração não é facilmente descartada. Um desses conjuntos de circunstâncias compreende a relação entre idade e identificação partidária. Como observamos, a teoria diria que a identificação partidária se torna mais forte e mais influente com a idade. $E$ é certo que nos painéis de 
Jennings, no painel intra-ano de 1980 e no painel de longo prazo 1972-1974-1976 a identificação partidária é consistentemente interpretável como "causa" com muito mais freqüência entre as pessoas mais velhas do que entre os jovens. Porém, com a mesma consistência, a identificação partidária exibe maior estabilidade (ou confiabilidade medida) entre os mais velhos. Sem maior precisão em nossa avaliação da incidência de erro de mensuração ou da centralidade relacionada com idade da identificação partidária, a conclusão de que essa identificação é com mais freqüência um agente causal entre os mais velhos do que entre os jovens permanece pelo menos vulnerável a críticas quando a conclusão se baseia em nossa análise causal de fluxo direcional de duas variáveis.

\section{Participação, educação e o papel causal da predisposição política}

Por outro lado, alguns outros resultados das primeiras explorações de nosso algoritmo tabular parecem menos vulneráveis às críticas baseadas na suposição de erro de mensuração. Ao examinar as diferenças em padrões causais para votantes e nãovotantes, por exemplo, as autocorrelações para praticamente todas as variáveis relevantes do painel 1990-1991-1992 são essencialmente as mesmas para ambos. Contudo, no painel do começo dos anos 90, nos painéis de 1980 e também nos de 19721974-1976, há diferenças persistentes entre votantes e não-votantes que sustentam diferentes interpretações causais dentro de cada um dos dois grupos de cidadãos. Ao fazer o teste para relações causais envolvendo identificação partidária, o partido aparece quase invariavelmente como "causa", com as preferências políticas aparecendo como "efeitos" entre os votantes. Em contraste, nos não-votantes entre 1972 e 1974, as atitudes em relação a direitos civis, o papel das mulheres na sociedade e os direitos dos acusados dominam a identificação partidária nas análises de mudança direcionais de duas variáveis, e por margens de 6 a 5, 10 a 7 e 8 a 7 respectivamente. Como mostra a Tabela 2, entre os votantes com menos do que escolaridade superior, as proporções que favorecem o partido como causa eram fortemente acentuadas. Por margens de 13 a 3, 13 a 6 e 15 a 4, a identificação partidária anterior influenciava as preferências nessas questões políticas mais do que o inverso. 
TABELA 2

Dominância causal dentro de pares de variáveis, identificação partidária e preferências políticas, 1972-1974 e 1974-1976, por participação do eleitor e instrução

\begin{tabular}{|c|c|c|c|c|c|c|}
\hline \multirow[b]{2}{*}{$\begin{array}{l}\text { "Outras" } \\
\text { variáveis }\end{array}$} & \multicolumn{2}{|c|}{ Não-votantes } & \multicolumn{2}{|c|}{$\begin{array}{c}\text { Votantes com menos } \\
\text { do que instrução superior }\end{array}$} & \multicolumn{2}{|c|}{$\begin{array}{c}\text { Votantes com pelo } \\
\text { menos alguma instrução } \\
\text { superior }\end{array}$} \\
\hline & $\begin{array}{c}I P \\
\text { dominante }\end{array}$ & $\begin{array}{c}\text { Outra } \\
\text { dominante }\end{array}$ & $\begin{array}{c}I P \\
\text { dominante }\end{array}$ & $\begin{array}{c}\text { Outra } \\
\text { dominante }\end{array}$ & $\begin{array}{c}I P \\
\text { dominante }\end{array}$ & $\begin{array}{c}\text { Outra } \\
\text { dominante }\end{array}$ \\
\hline \multicolumn{7}{|l|}{ Ideologia } \\
\hline $1972-1974$ & 3 & 2 & 11 & 3 & 8 & 7 \\
\hline 1974-1976 & 4 & 2 & 11 & 2 & 7 & 5 \\
\hline \multicolumn{7}{|l|}{$\begin{array}{l}\text { Auxílio às } \\
\text { minorias }\end{array}$} \\
\hline $1972-1974$ & 8 & 8 & 15 & 5 & 9 & 6 \\
\hline $1974-1976$ & 4 & 4 & 18 & 4 & 10 & 6 \\
\hline \multicolumn{7}{|l|}{$\begin{array}{l}\text { Direitos dos } \\
\text { acusados }\end{array}$} \\
\hline $1972-1974$ & 5 & 6 & 13 & 3 & 8 & 2 \\
\hline 1974-1976 & 7 & 7 & 14 & 4 & 13 & 5 \\
\hline \multicolumn{7}{|l|}{$\begin{array}{l}\text { Papel das } \\
\text { mulheres }\end{array}$} \\
\hline $1972-1974$ & 7 & 10 & 13 & 6 & 9 & 8 \\
\hline 1974-1976 & 7 & 4 & 11 & 6 & 8 & 5 \\
\hline \multicolumn{7}{|l|}{$\begin{array}{l}\text { Emprego \& } \\
\text { padrões de } \\
\text { vida }\end{array}$} \\
\hline $1972-1974$ & 10 & 3 & 11 & 5 & 9 & 5 \\
\hline 1974-1976 & 9 & 5 & 15 & 4 & 13 & 6 \\
\hline \multicolumn{7}{|l|}{$\begin{array}{l}\text { Perdão } \\
\text { presidencial }\end{array}$} \\
\hline 1974-1976 & 5 & 14 & 8 & 10 & 7 & 10 \\
\hline
\end{tabular}

${ }^{a}$ Os números são proporções de toda a população do painel que refletem relações causais plausíveis. O número de casos varia; o máximo é 1270 
De modo mais geral, em ambos os intervalos de 1972-1974 e 1974-1976, instâncias em que as variáveis eram relativamente iguais na freqüência com que apareciam como "causa plausível", ou instâncias em que o partido era dominado pela variável relacionada com a questão política foram encontradas somente entre os nãovotantes. O contraste foi proporcionado pelos votantes com menos do que escolaridade superior; entre eles, o partido sempre dominava como "causa provável", e por proporções de quase três para um, em média. Entre os votantes com alguma educação superior, os efeitos eram mais equilibrados - o partido também era dominante, mas por margens menores. O papel dominante da identificação partidária como "a causa" era mais evidente na disputa com o conceito mais ou menos abstrato de preferências ideológicas liberais ou conservadoras.

Ao menos uma exceção notável a esse padrão ocorreu no interlúdio 1974-1976 nas atitudes com respeito ao perdão dado pelo presidente Ford ao ex-presidente Nixon. Entre os votantes, assim como entre os não-votantes, o controvertido perdão produziu o padrão dominante de mudanças. O partido influenciou a aprovação relativa da generosidade do sr. Ford com muito menos freqüência do que a identificação partidária mudou devido a atitude em relação ao perdão.

Quando a ideologia (auto-classificação numa escala liberal-conservadora) substitui a identificação partidária nos pares de variáveis específicos das políticas nos painéis de 1972-1974 ou 1974-1976 (ver Tabela 3), os votantes com mais escolaridade oferecem de modo bastante uniforme provas de instâncias em que as predisposições ideológicas moldam as preferências em questões políticas com mais freqüência do que são moldadas por elas.

As posições anteriores com respeito às questões parecem dominar uniformemente a ideologia entre os não-votantes; o mesmo vale para os votantes com menos escolaridade, por uma margem um pouco menor. Em todas as cinco questões políticas disponíveis para exame, a ordenação de nossos três grupos de cidadãos estava clara: preferências em questões específicas moldadas por preferência ideológica eram relativamente menos numerosas somente entre os votantes com escolaridade superior. No outro extremo estavam os não-votantes, entre os quais a ideologia raramente dominava no contexto com preferências em questões específicas. 
TABELA 3

Dominância causal dentro de pares de variáveis, ideologia e preferências políticas, 1972-1974 e 1974-1976, por participação do eleitor e instrução ${ }^{a}$

\begin{tabular}{|c|c|c|c|c|c|c|}
\hline \multirow[b]{2}{*}{$\begin{array}{l}\text { "Outras" } \\
\text { variáveis }\end{array}$} & \multicolumn{2}{|c|}{ Não-votantes } & \multicolumn{2}{|c|}{$\begin{array}{c}\text { Votantes com menos } \\
\text { do que instrução superior }{ }^{2}\end{array}$} & \multicolumn{2}{|c|}{$\begin{array}{c}\text { Votantes com pelo } \\
\text { menos alguma instrução } \\
\text { superior }\end{array}$} \\
\hline & $\begin{array}{c}\text { IP } \\
\text { dominante }\end{array}$ & $\begin{array}{c}\text { Outra } \\
\text { dominante }\end{array}$ & $\begin{array}{c}I P \\
\text { dominante }\end{array}$ & $\begin{array}{c}\text { Outra } \\
\text { dominante }\end{array}$ & $\begin{array}{c}I P \\
\text { dominante }\end{array}$ & $\begin{array}{c}\text { Outra } \\
\text { dominante }\end{array}$ \\
\hline \multicolumn{7}{|l|}{$\begin{array}{l}\text { Auxílio às } \\
\text { minorias }\end{array}$} \\
\hline 1972-1974 & 3 & 7 & 5 & 9 & 9 & 6 \\
\hline 1974-1976 & 4 & 7 & 4 & 8 & 8 & 7 \\
\hline \multicolumn{7}{|l|}{ Direitos civis } \\
\hline 1972-1974 & 2 & 4 & 4 & 9 & 9 & 4 \\
\hline $1974-1976$ & 2 & 6 & 4 & 6 & 8 & 7 \\
\hline \multicolumn{7}{|l|}{$\begin{array}{l}\text { Direitos dos } \\
\text { acusados }\end{array}$} \\
\hline 1972-1974 & 3 & 6 & 4 & 6 & 8 & 7 \\
\hline $1974-1976$ & 0 & 4 & 4 & 7 & 10 & 6 \\
\hline \multicolumn{7}{|l|}{$\begin{array}{l}\text { Papel das } \\
\text { mulheres }\end{array}$} \\
\hline 1972-1974 & 2 & 11 & 6 & 9 & 8 & 8 \\
\hline 1974-1976 & 1 & 6 & 3 & 5 & 6 & 6 \\
\hline \multicolumn{7}{|l|}{$\begin{array}{l}\text { Emprego \& } \\
\text { padrões de } \\
\text { vida }\end{array}$} \\
\hline 1972-1974 & 4 & 7 & 4 & 6 & 9 & 7 \\
\hline 1974-1976 & 4 & 6 & 5 & 8 & 12 & 9 \\
\hline
\end{tabular}

${ }^{a}$ Os números são proporções de toda a população do painel que refletem relações causais plausíveis. $\mathrm{N}$ é aproximadamente 1270

Os dois painéis da década de 1970 dão sustentação à série de generalizações de interesse direto para nossa investigação. (1) Na análise das preferências dos votantes, é dominante a ordem que tem a identificação partidária precedendo a auto-classificação ideológica que, por sua vez, precede as preferências em questões políticas específicas. (2) Esse caso ocorre com mais freqüência entre os votantes menos instruídos do que entre aqueles que têm alguma escolaridade superior. (3) Mesmo nos contextos em que essa generalização é mais claramente verdadeira, uma quantidade substancial de votantes reflete seqüências temporais de mudança em que o partido parece ser moldado para se conformar a predisposições ideológicas estáveis ou preferências por políticas específicas. (4) Entre os não-votantes, essas preferências parecem moldar as preferências ideológicas com mais freqüência do que o inverso. (5) Entre os não-votantes, 
o partido era raramente dominante como causa de mudanças de atitude relacionadas com questões políticas específicas.

Idade, educação e comparecimento eleitoral foram tratados aqui como variáveis "condicionais", introduzidas para testar a ordenação de identificação partidária, predisposições ideológicas e preferências em questões políticas específicas. Não surpreende que isso tenha exposto também relações pertinentes a preocupações mais amplas com a natureza e a mensuração da opinião pública. O uso "efetivo" de predisposições ideológicas abstratas está apropriadamente associado ao envolvimento político (votar) e à instrução; o partidarismo parece ter seu maior impacto nos votantes menos instruídos; e a periferia política reage mais às questões individuais e dramáticas Watergate e o perdão presidencial, a mudança do papel das mulheres na sociedade, ajuda às minorias e crime. E sem esquecer a clássica designação de Converse de "nãoatitudes", a presença ubíqua de mudança dissonante ou discordante em preferências em questões políticas é notável, particularmente entre os membros mais periféricos do eleitorado, os não-votantes. Para nossos propósitos aqui, esses ecos das contribuições mais convencionais à literatura sobre a formação e organização das atitudes políticas acrescentam credibilidade à significância de nosso algoritmo tabular (ver Converse 1962; Zaller 1992).

\section{Mudança induzida por campanha em 1980}

No decorrer da campanha de 1980, o enorme número de pessoas que exibiam possíveis padrões causais na mudança de relações entre partido e ideologia era aproximadamente proporcional ao número em outros períodos mais longos captados por painéis de longo prazo. Entre janeiro e junho de 1980, 11\% dos membros do painel de 1980 mudaram suas auto-classificações ideológicas, alinhando-os com suas identificações partidárias imutáveis; somente $6 \%$ refletiram mudanças em partido que estavam em maior conformidade com sua localização ideológica. Entre junho e outubro daquele ano eleitoral, a proporção foi ainda maior, com $12 \%$ favorecendo a identificação partidária como a causa provável e somente $4 \%$ revelando posições ideológicas estáveis acompanhadas por mudanças congruentes de partido. Essa mudança refletia possivelmente o equilíbrio cambiante de influências de longo prazo/curto prazo produzido pela aproximação da eleição presidencial de 1980.

É interessante observar que a natureza singular do ano da ascendência de Reagan é sugerida pelo fato de que, particularmente na primeira metade do ano, a lealdade ao partido Democrata superou os republicanos no papel causal, enquanto que as predisposições conservadoras superaram claramente as liberais entre aqueles para os quais a ideologia era a causa presumível dominante (de mudanças em identificação partidária favorecendo os republicanos). De qualquer modo, se esse par de intervalos de tempo é de alguma forma típico dos anos de eleição presidencial, a seqüência partidoideologia predomina antes da campanha e domina amplamente à medida que a eleição se 
aproxima.

Isso era válido tanto para cidadãos mais velhos, onde aumentava a dominância da identificação partidária sobre as atitudes em relação aos serviços e aos gastos governamentais, como para os de menos de 45 anos. Porém, uma diferença notável de idade existia nas direções partidárias das influências dominantes. No grupo mais velho, dois terços daqueles cujas identificações partidárias aparentemente moldavam suas preferências em questões políticas eram democratas - somente um terço era republicano. Em conseqüência, entre eles, as preferências em políticas deslocaram-se para o lado liberal. No grupo mais jovem, a divisão partidária era de somente 49 democratas para 51 republicanos. E entre as gerações mais jovens, onde as preferências em questões políticas eram muito menos moldadas por simpatias democratas do que entre os mais velhos, essas preferências mudaram mais para o lado conservador. Ao mesmo tempo, porém, entre os jovens, somente $30 \%$ dos que mudaram de identificação partidária (para combinar melhor com as preferências em políticas) estavam reagindo a preferências conservadoras, enquanto que no grupo mais velho, $45 \%$ do grupo relativamente menor que estava mudando de partido o faziam pelo mesmo motivo. Como uma análise anterior da eleição de 1980 podia apenas sugerir, esta análise documenta o fato de que os eleitores mais jovens (que mudaram de preferências políticas) eram com mais freqüência republicanos e (entre os que mudaram de partido), mais liberais do que os mais velhos - o que contribuía para uma interessante tensão entre futuras lealdades e preferências, pelo menos entre aqueles jovens eleitores que mudaram suas preferências e lealdades durante o ano eleitoral de 1980 (Miller e Shanks 1982).

\section{Outras implicações derivadas da representação tabular da influência causal}

Trabalhando ainda com o painel de 1980, há dados adicionais de que as configurações de mudança que estamos observando são reais e significativas, não aleatórias e efêmeras. Em concordância com as expectativas teóricas, não surpreende descobrir que os que se identificam com partidos "fortes" refletem uma unanimidade virtual na ausência de mudança "ideologicamente causada" e na dominância de suas lealdades partidárias. Eles também refletem a instância mais baixa de mudança em ambas as variáveis e o número menor de casos de mudança "não interpretável". Por outro lado, os independentes, ou eleitores sem preferência partidária, exibem a menor estabilidade, a maior propensão a mudanças aparentemente aleatórias e uma incidência visivelmente maior de mudança atribuível à ideologia.

Numa dimensão bem diferente, os padrões de mudança atitudinal parecem estar relacionados com o envolvimento do cidadão em política. Aqueles que dizem acompanhar quase sempre os assuntos públicos são os menos inclinados a mudar as preferências políticas; os que raramente fazem isso, são mais voláteis e apresentam com mais freqüência mudanças que não se rendem a uma interpretação fácil, enquanto que os bons cidadãos costumam mudar de um modo interpretável. Ao mesmo tempo, o interesse 
dos cidadãos na campanha em curso apresenta uma variante interessante sobre o tema. Menos mudança em atitudes políticas está associada a menos atenção à campanha, mas é a categoria média - aqueles que se interessam "um pouco" pela campanha - a mais volátil e a mais provável de mudar de maneira inesperada. Isso lembra a relação curvilinear freqüentemente observada entre envolvimento político e suscetibilidade à mudança. Aqueles que não se engajam nem perifericamente à campanha em curso são menos abertos à mudança; os que dão mais atenção são muito mais abertos, mas sua mudança - no curto prazo - é amiúde errática; os que se envolvem mais profundamente não mudam muito ou com freqüência (supostamente ancorados pelo peso de seu conhecimento de política), mas quando mudam, a mudança parece interpretável.

Devido ao rico banco de dados proporcionado pelo atual desenho de estudo do NES, as investigações detalhadas da política nos anos 80 prometem mais insights sobre as influências causais que modelam a opinião pública. Em 1994, foram acrescentadas medidas de predisposições relativas ao igualitarismo e a tolerância moral à identificação partidária e à auto-classificação ideológica como medidas baseadas em painel de predisposições relacionadas com políticas relevantes para as preferências em políticas dos eleitores. Usando dados do painel 1992-1994 em nossos algoritmos tabulares, o partido geralmente domina a ideologia, que domina a tolerância moral que, por sua vez, domina o igualitarismo. Algo da disposição peculiar da época pode ser captado pelo grau em que as preferências em questões como ação afirmativa, pena de morte, auxílio a cidadãos negros e limites de mandato pareciam influenciar todas as quatro predisposições, supostamente mais genéricas. A dominância delas sobre o igualitarismo era particularmente notável. Ao mesmo tempo, ou pelo menos no mesmo período, as atitudes em relação ao seguro saúde e aos serviços e gastos domésticos do governo estavam mudando para concordar melhor com as mesmas predisposições, e sobretudo com a identificação partidária. 


\section{Conclusão}

Estes vários exemplos ilustram algumas das possíveis conseqüências de estabelecer as credenciais de nosso paradigma tabular para avaliar a direção causal das relações entre duas variáveis inter-relacionadas. O procedimento pode aparentemente iluminar muitos aspectos das origens e conseqüências dos antecedentes da decisão de voto, bem como sugerir uma dominante ordenação entre subconjuntos de variáveis unidas em uma única equação explicativa. Porém, tendo em vista a natureza pragmática, presa aos dados, deste experimento em particular na explicação causal, é difícil ver todas as implicações, ou falta delas, do que descobrimos. Muito do que observamos foi interessante e provocador, mas foi selecionado para apresentação com talvez pouca apreciação de todas as proposições metodológicas que poderiam ser invocadas.

Ao mesmo tempo, está claro que concentramos nossa atenção com mais agudeza na seqüência temporal da mudança do que é possível com usos mais ortodoxos de estatística correlacional ou de regressão. Voltando por um momento à nossa descrição dos padrões de estabilidade e mudança produzidos por nossas manifestações tabulares, algo em torno de um quarto de cada painel esteve envolvido em todos os padrões de mudança que julgamos interpretáveis em termos de mudança direcional causada. Os restantes três quartos foram divididos em (2) casos que não exibiam nenhuma mudança em ambas as variáveis e (3) casos de divergência em direções "opostas". A segunda categoria reflete aparentemente relações estáticas estabelecidas em algum momento anterior; a terceira desafia qualquer interpretação causal direcional da interação entre as duas variáveis. Não obstante, as três categorias desempenham um papel em estimativas agregadas da relação total (correlação) entre $A$ e $B$ tanto em $T_{1}$ como em $T_{2}$ e, portanto, em mudanças em coeficientes que resumem as relações entre $T_{1}$ e $T_{2}$. $O$ isolamento daqueles casos para os quais uma seqüência temporal observada de mudanças em variáveis individuais parece "fazer sentido" ofereceria um acesso mais direto à análise das relações tal como elas mudam ao longo do tempo.

Os dados de painel que examinamos em nossa busca da ordem temporal que deve sustentar inferências causais válidas baseadas em dados longitudinais deram quase invariavelmente suporte à expectativa de que a identificação partidária anterior leva a mudanças na ideologia liberal/conservadora dos eleitores, com mais freqüência do que a ideologia estável leva a mudanças congruentes na identificação partidária. O partido tem sido mais dominante entre votantes moderadamente instruídos; a ideologia aparece com mais freqüência no papel de motor principal entre os votantes com instrução superior.

Entre os não-votantes, nem a identificação partidária nem a ideologia aparecem com a mesma freqüência como causa do aumento de congruência nas preferências em questões políticas, sendo que a ideologia é menos freqüentemente dominante como causa de mudança. 
A identificação partidária aparece dominante com mais freqüência como causa de mudança de atitude entre eleitores mais velhos. Nas comparações do painel de Jennings entre pais e filhos, ideologia e questões políticas eram designadas "causadoras" com mais freqüência entre jovens adultos (a coorte dos filhos) do que entre cidadãos da geração dos pais.

As diferenças associadas à idade, escolaridade e participação política dos eleitores estão todas convenientemente associadas com expectativas teóricas estabelecidas relativas aos papéis causais da identificação partidária, ideologia como predisposição relacionada a políticas e preferências quanto a políticas específicas. Entre nossas descobertas, talvez tenha importância igual a documentação do grau em que as influências causais são contrariadas por fluxo causal aparente na direção oposta. Podemos nos sentir satisfeitos com o fato de que a seqüência IP $\rightarrow I D \rightarrow$ Questões é dominante entre os votantes, mas também é verdade que a inversão dessa ordem causal pode caracterizar uma minoria muito visível, se não uma maioria ocasional, dentro da população heterogênea dos eleitores da nação. Por fim, a evidência de ordem e coerência na organização de opiniões de massa não nega a presença contínua de muitas, muitas não-atitudes e preferências conflitantes, entre os eleitores mais escolarizados e aqueles cidadãos mais periféricos à política e às eleições nacionais.

\section{BIBLIOGRAFIA}

ALWIN, D. P. \& HAUSER, R. M. (1975) The Decomposition of Effects in Path Analysis. American Sociological Review, 40:37-47.

BARTELS, Larry. (1988) Presidential Primaries and the Dynamics of Public Choice. Princeton, NJ: Princeton University Press.

BLALOCK, Hurbert M., Jr. (1961) Causal Inferences in Nonexperimental Research. Chapel Hill: University of North Carolina Press.

. (1971) Causal Models in the Social Sciences. Nova York: Aldine/Atherton.

BRADY, Henry \& JOHNSTON, Richard. (1987) What's the Primary Message: Horse Race or Issue Journalism. In: Media and Momentum, eds. Gary R. Orren e Nelson W. Polsby. Chatham, NJ, pp. 127-186.

BRODY, Richard A. \& PAGE, Benjamin I. (1972) The Assessment of Policy Voting. American Political Science Review, 66:450-458.

et al. (1969) Vietnam, the Urban Crisis and the 1968 Election. Trabalho apresentado na Reunião Anual da American Sociological Association, San Francisco.

CAMPBELL, A., CONVERSE, Philip E., MILLER, Warren E. \& STOKES, Donald E. (1976) The American Voter. Chicago: University of Chicago Press.

CAMPBELL, James \& GARAND, James. (2000) Before the Vote: Forecasting the 1996 American National Elections. Thousand Oaks, CA: Sage.

CONVERSE, Philip E. (1962) Information Flow and Stability of Partisan Attitudes. Public Opinion Quarterly, 26:578-599. 
(1964) The Nature of Belief Systems in Mass Publics. In: Ideology and Discontent, ed. David Apter. Nova York: Free Press.

DAVIS, James A. (1985) The Logic of Causal Order. Beverly Hills, CA: Sage.

FIORINA, Morris P. (1981) Retrospective Voting in American National Elections. New Haven, CT: Yale University Press.

GEER, John. (1988) What Do Open-Ended Questions Measure? Public Opinion Quarterly, 52:365370.

GREEN, Donald P. \& PALMQUIST, Bradley. (1990) Of Artifacts and Partisan Instability. American Journal of Political Science, 34:872-902.

JACKSON, John E. (1975) Issues, Parties and Presidential Votes. American Journal of Political Science, 19:167-185.

JENNINGS, M. Kent \& MARKUS, Gregory B. (1984) Partisan Orientations over the Long Haul: Results from the Three-Wave Political Socialization Panel Study. American Political Science Review, 78:1000-1018.

\& NIEMI, Richard G. (1981) Generations and Politics: A Panel Study of Young Adults and Their Parents. Princeton, NJ: Princeton University Press.

KENDALL, Patricia L. \& LAZARSFELD, Paul F. (1950) Problems of Survey Analysis. In: Continuities in Social Research: Studies in the Scope and Method of "The American Soldier," eds. R. K. Merton e P. P. Lazarsfeld. Glencoe, IL: Free Press, pp. 148-154.

MILLER, Warren E. \& SHANKS, J. Merrill. (1982) Policy Directions and Presidential Leadership: Alternative Interpretations of the 1980 Presidential Election. British Journal of Political Science, 12:299-356. . (1996) The New American Voter. Cambridge, MA: Harvard University Press.

RABINOWITZ, George \& MacDONALD, Elaine Stuart. (1989) A Directional Theory of Issue Voting. American Political Science Review, 83:93-121.

ROSENBERG, Morris. (1968) The Logic of Survey Analysis. Nova York: Basic Books.

SHANKS, J. Merill \& MILLER, Warren E. (1990) Policy Direction and Performance Evaluation: Complementary Explanation of the Reagan Elections. British Journal of Political Science, 20:143-235.

(1991) Partisanship, Policy and Performance: The Reagan Legacy in the 1988 Election. British Journal of Political Science, 21:129-197.

TEIXEIRA, Ruy. (1984) Why Americans Don't Vote. Westwood: Greenwood Press.

WRIGHT, Sewall. (1921) Correlation and Causation. Journal of Agricultural Research, 20:557-585.

ZALLER, John. (1992) The Nature and Origins of Mass Opinions. Nova York: Cambridge University Press.

Tradução do original em inglês de Pedro Maia Soares 